\title{
Salix herbacea L. (Salicaceae) in the Maramures massif of the Ukrainian Carpathians
}

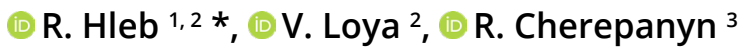 \\ ${ }_{1}^{1}$ Carpathian Biosphere Reserve, Krasne Pleso str. 77, 90600 Rakhiv, Ukraine; * gleb.ruslan@gmail.com \\ 2 M.M. Gryshko National Botanical Garden, National Academy of Sciences of Ukraine, Timiryazevska str. 1, 01014 Kyiv, Ukraine \\ ${ }^{3}$ Vasyl Stefanyk Precarpathian National University, Shevchenko str. 57, 76018 Ivano-Frankivsk, Ukraine
}

Received: 19.02 .2020 | Accepted: 09.05.2020 | Published: 30.06 .2020

\begin{abstract}
Salix herbacea is a relict plant species related to the circumpolar arctic-alpine element of the Holarctic group. The aim of the study was to clarify the data on the distribution of $S$. herbacea within the Maramures massif of the Ukrainian Carpathians since this species is reported by different authors for the massif without specific geographical and habitats descriptions. Field studies were conducted in the Maramures massif on the slopes of Pip Ivan Marmarosky (1936 m a.s.l.) and Rapa (1872 m a.s.l.) mountains in 20172019. The S. herbacea distribution chorology was analyzed based on the inventory of UU, KW, KWHA, LW, Herbarium of the Carpathian Biosphere Reserve, and Herbarium of the Biology and Ecology Department of the Vasyl Stefanyk Precarpathian National University collections. We have found S. herbacea confined to cliffs on a rocky tourist path between the peaks of Pip Ivan Marmarosky and Rapa mountains in the Rakhiv district of the Transcarpathian region (Zakarpattia oblast). Recently, these rocky formations were occupied by tall grasses such as Calamagrostis villosa, Poa pratensis and Festuca picturata. Meanwhile, the occurrence of Holarctic and Alpine-Carpathian species Vaccinium uliginosum, Potentilla aurea, Pulsatilla alba, Thamnolia vermicularis and Cetraria islandica substantially decreased. These changes were probably caused by a decrease in livestock grazing intensity during the past years in this area, as well as more favorable climate conditions for tall grass species. The exact location and phytocoenological conditions of the site, which is endangered and requires additional conservation measures, were outlined. The necessity of these measures to preserve the habitat of $S$. herbacea on the Maramures massif was stressed out.
\end{abstract}

Keywords: Salix herbacea, Ukrainian Carpathians, Maramures, herbarium collections, distribution, protection

\section{Introduction}

The genus Salix L. comprises about 450 species in the world flora (Argus et al., 2010), with 24 species represented in the flora of Ukraine (Gorelov, 2002; Fuchylo \& Sbytna, 2009). There are 18 Salix species distributed in the Ukrainian Carpathians and Transcarpathia, including 15 species distributed on the territory of the Carpathian Biosphere Reserve. Six Salix species are listed in the Red Book of Ukraine: S. alpina Scop., S. lapponum L.,
S. myrtilloides L., S. starkeana Willd., S. herbacea L., and S. retusa L. (Didukh, 2009).

Salix herbacea is a relict species related to the circumpolar arctic-alpine element of the Holarctic group (Meusel et al., 1965; Malynovskyi, 1980; Didukh, 2009). It is common in the Arctic as well in North America, whereas in Central and Southern Europe, it becomes progressively less frequent (Tralau, 1963; Jalas \& Suominen, 1976; Elven \& Karlsson, 2000). It is a perennial shrub, chamaephyte, $10-30 \mathrm{~cm}$ tall, with 


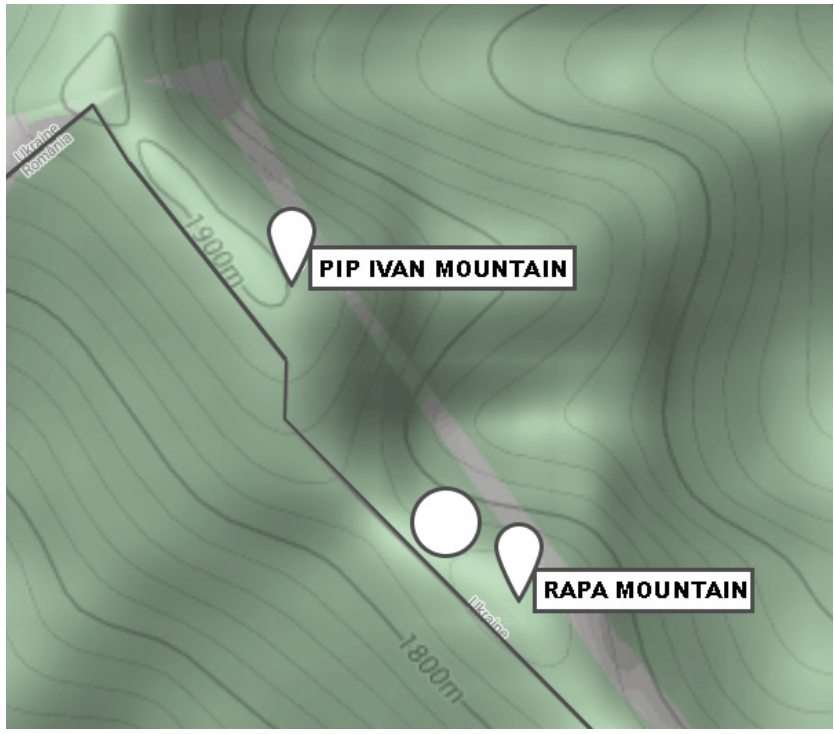

Figure 1. The location of the discovered Salix herbacea population (white circle) on the Maramures massif.

well developed underground stolons. In the Ukrainian Carpathians S. herbacea, habitats are limited to rocky outcrops and sites in the alpine and subalpine vegetation belts. The only few known populations of $\mathrm{S}$. herbacea occur in the summit areas of Chornohora, Svydovets, and Maramures, where they cover relatively small areas (Didukh, 2009; Prokopiv \& Volgin, 2009; Kobiv, 2010). Populations of S. herbacea in the Ukrainian Carpathians are endangered due to the growing anthropogenic pressure and obviously could be under the impact of climate change in the future (Kobiv, 2009). At present, detailed information about localities, habitat preferences, and floristic composition of communities with S. herbacea in the Maramures Mts. is absent. Hence, this investigation aimed to clarify it.

\section{Material and methods}

Field studies were conducted in the Maramures massif on the slopes of the Pip Ivan Marmarosky (1936 m a.s.l.) and Rapa (1872 m a.s.l.) mountains in 2017-2019 (Fig. 1). This territory is a part of the Carpathian Biosphere Reserve. The location of the habitat was determined using a GPS navigator Garmin eTrex 30x with an accuracy of up to 10 meters.

The names of the plant taxa are given according to The Plant List (2013), the names of the lichen taxa are given according to MycoBank (2020).
Vegetation description was performed using the Braun-Blanquet approach (Yaroshenko, 1961; Braun-Blanquet, 1964). Herbarium collections were transferred to the herbarium of the Carpathian Biosphere Reserve and the herbarium of the M.M. Gryshko National Botanical Garden, National Academy of Sciences of Ukraine (KWHA). The S. herbacea distribution was analyzed based on the inventory of vouchers preserved in the UU, KW, KWHA, LW (see Index Herbariorum (Thiers, 2020) for acronyms), Herbarium of the Carpathian Biosphere Reserve and Herbarium of the Biology and Ecology Department of the Vasyl Stefanyk Precarpathian National University.

\section{Results}

Different authors provided data on the present occurrence of S. herbacea in the Maramures massif (Dobrochaeva et al., 1987; Kricsfalusy, 1982, 1999; Didukh, 2009; Kobiv et al., 2017). Malynovskyi (1980) reported S. herbacea from the Polytrichetum sexangularis Br.-Bl. 1926 basing on Deyl (1940), who was the first to describe this association for the Maramures massif. However, neither Malynovskyi (1980) nor Deyl (1940) provided details about the presence of S. herbacea here. Moreover, the dwarf willow is mentioned for Maramures in the Flora of the USSR (Nazarov et al., 1952), but also there without providing precise locations and without the support of observed herbarium vouchers.

Specimens of $\mathrm{S}$. herbacea from the Maramures massif were found only in the National Herbarium of Ukraine at the M.G. Kholodny Institute of Botany of the National Academy of Sciences of Ukraine, Kyiv (KW): 1) Zakarpattia Region, Rakhivs'kyi District, Pip Ivan Marmarosky mountain, 1890 m a.s.l., Hryn' F., 07.07.1948; 2) 1900 m a.s.l., Bradis E., Zapjatova A., 21.07.1948; 3) 1960 $m$ a.s.l., Bradis E., Zapjatova A.21.07.1948;

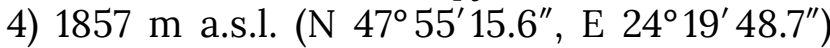
Nachychko V.O., Kobiv Y.Y., Borsukevych L.M., 28.07.2016.

All mentions of the occurrence of S. herbacea in the Maramures massif probably concerned the only population. It is located between the peaks of Pip Ivan Marmarosky and Rapa mountains of 
the Maramures massif (Rakhiv district of Transcarpathian region, at the border of Ukraine and Romania), which also we have observed and investigated close to a rocky tourist path (Fig. 1). The population covers an area of about $200 \mathrm{~m}^{2}$ at an elevation of about $1860 \mathrm{~m}$ a.s.l. The upper points

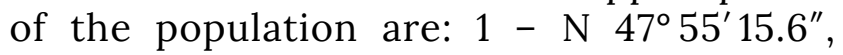

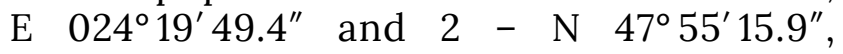
E $024^{\circ} 19^{\prime} 48.4^{\prime \prime}$, and the lower points are 3 - N 47 $55^{\prime} 16.89^{\prime \prime}$, E $024^{\circ} 19^{\prime} 49.76^{\prime \prime}$ and $4-\mathrm{N} 47^{\circ} 55^{\prime} 16.96^{\prime \prime}$, E $024^{\circ} 19^{\prime} 48.47^{\prime \prime}$ (Figs. 2 \& 3).

The shrub layer is represented predominantly by the following species: Vaccinium myrtillus L., V. uliginosum L., Rhododendron myrtifolium Schott \& Kotschy, and S. herbacea (Table 1). Vascular plants cover from 40 to $90 \%$ of the surface. The rest of the surface is occupied by lichens and mosses (i.e., Thamnolia vermicularis (Sw.) Ach. ex Schaer., Cetraria islandica (L.) Ach., Cladonia rangiferina (L.) Weber ex F.H. Wigg., Dicranum scoparium Hedw. Polytrichastrum alpinum (Hedw.) G.L. Sm. Polytrichum commune Hedw., and P. strictum Menzies ex Brid.), by bare soil and by soil eroded by the passage of tourists, and by the rocky limestone outcrops of. S. herbacea covers approximately $7-20 \%$ of the habitat area. The prevailing species are: Soldanella hungarica Simonk., Vaccinium myrtillus, Rhododendron myrtifolium, Ligusticum mutellina (L.) Crantz, Carex sempervirens Vill., and Juncus trifidus L. The base of the rocky outcrops is colonized by tall-grasses such as Calamagrostis villosa (Chaix) J.F. Gmel., Poa pratensis L., Festuca picturata Pils. Moreover, the occurrence of the holarctic and Alpine-Carpathian species Vaccinium uliginosum L., Potentilla aurea L., Pulsatilla alba Reichenb., Thamnolia vermicularis, and Cetraria islandica was particularly relevant (Fig. 3). The occurrence of tall grasses and forbs resulted from the decrease of livestock grazing intensity in this area in the past years.

\section{Conclusions}

As a result of an inventory of certain herbarium collections, it was found that vouchers of S. herbacea hosted at the KW are the only known from the Maramures massif, and all of them referenced to the Pip Ivan

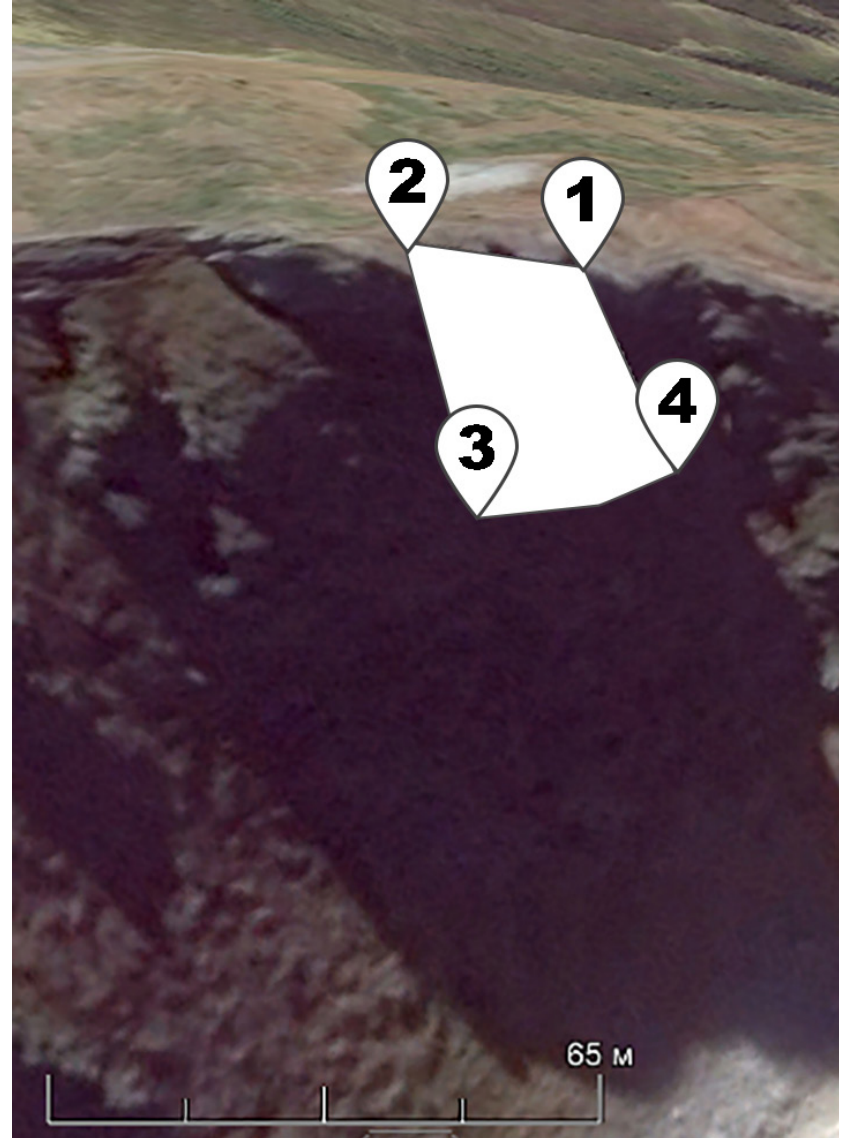

Figure 2. The site where Salix herbacea was sampled on the Maramures massif.

Marmarosky. However, all these reports of S. herbacea most probably concerned the only population between the peaks of Pip Ivan Marmarosky and Rapa mountains of the Maramures massif.

The area of the identified habitat of S. herbacea on the rocky tourist path between the peaks of Pip Ivan Marmarosky and Rapa mountains in the Maramures massif is about $200 \mathrm{~m}^{2}$. The cover of the species in the habitat ranges from 7 to $20 \%$.

Recently, the site was partially occupied by tall grasses such as Calamagrostis villosa, Calamagrostis arundinacea, Poa pratensis, Festuca picturata, and the occurrence of Holarctic and Alpine-Carpathian species substantially decreased. It is probably caused by a decrease in livestock grazing in the area and more favorable climate conditions for tall grass species.

Taking into account observed transformations, it is necessary to develop and implement urgent conservation measures to save the population of S. herbacea on the Maramures massif. 


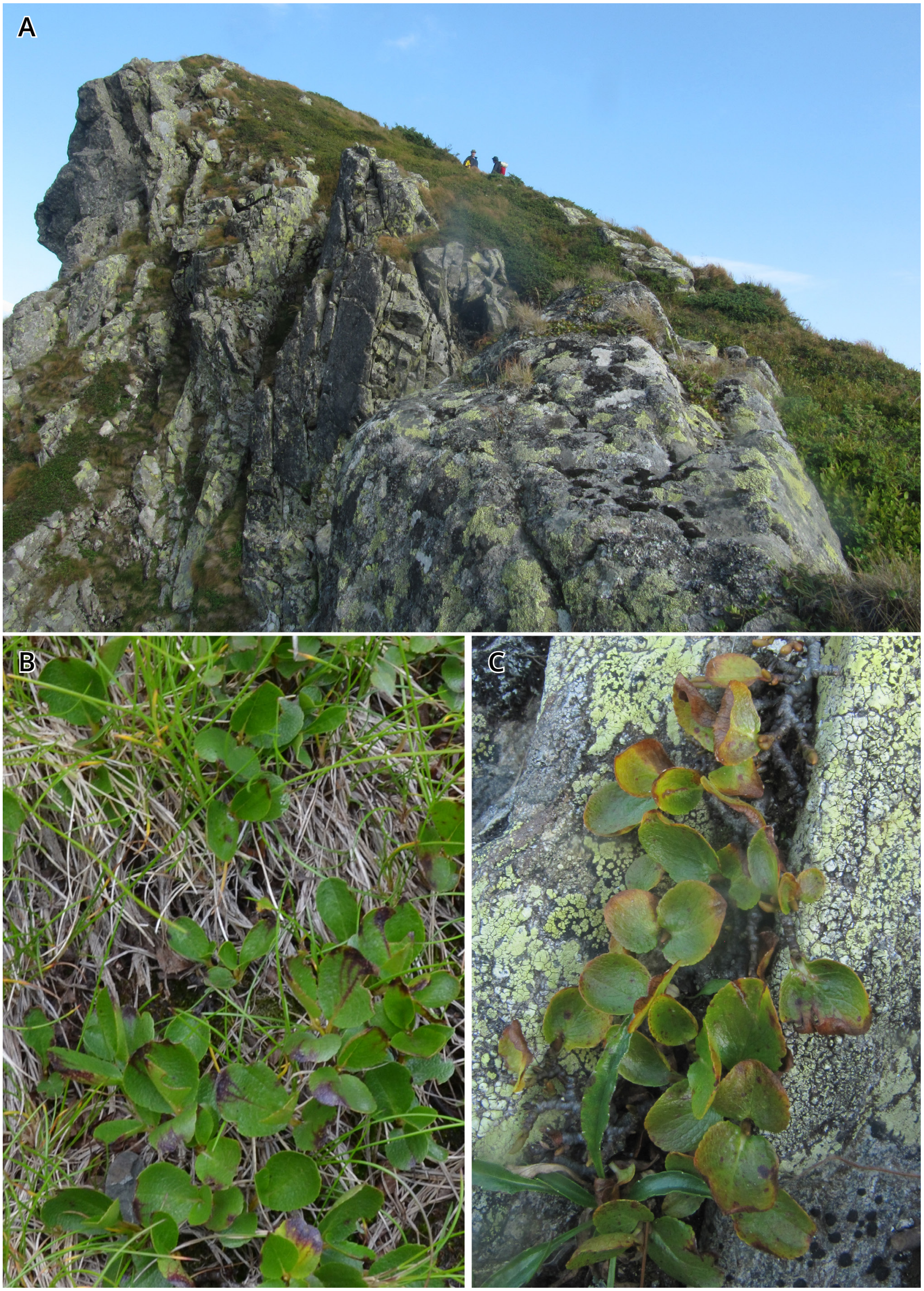

Figure 3. Salix herbacea on the Maramures massif: A - general habitat view, B - the lower overgrown part, $\mathrm{C}$ - the upper part. 
Table 1. Floristic composition of the plant community with Salix herbacea on the Maramures massif.

\begin{tabular}{|c|c|c|c|}
\hline \multicolumn{2}{|c|}{ 27.07.2017; 22.07.2019 } & \multirow{2}{*}{$\begin{array}{l}\text { Homogyne alpina (L.) Cass. } \\
\text { Hypericum richeri Vill. }\end{array}$} & \multirow{2}{*}{$\begin{array}{l}1 \\
2\end{array}$} \\
\hline Area, $\mathrm{m}^{2}$ & 200 & & \\
\hline Elevation (m a.s.l.) & $1853-1853$ & Luzula alpinopilosa (Chaix) Breistr. & 2 \\
\hline Aspect & $\mathrm{NE}$ & Poa pratensis L. & 2 \\
\hline Inclination $\left({ }^{\circ}\right)$ & $10-65$ & Campanula alpina Jacq. & + \\
\hline Cover of shrub layer (\%) & 30 & Solidago virgaurea L. subsp. minuta (L.) Arcang. & 1 \\
\hline Rhododendron myrtifolium Schott \& Kotschy & 2 & Veratrum lobelianum Bernh. & 1 \\
\hline Salix herbacea L. & 2 & Veronica fruticans Jacq. & + \\
\hline Vaccinium myrtillus L. & 1 & Deschampsia cespitosa (L.) P. Beauv. & 1 \\
\hline Vaccinium uliginosum L. & 1 & Potentilla aurea $\mathrm{L}$. & 1 \\
\hline Cover of herb layer (\%) & 60 & Hieracium alpinum $\mathrm{L}$. & 1 \\
\hline Agrostis sp. & 2 & Carex sempervirens Vill. & 1 \\
\hline Calamagrostis arundinacea (L.) Roth & 2 & Huperzia selago (L.) Bernh. ex Schrank \& Mart. & + \\
\hline Calamagrostis villosa (Chaix) J.F. Gmel. & 2 & Campanula polymorpha Witasek & 1 \\
\hline Ligusticum mutellina (L.) Crantz & 2 & Pulsatilla alba Reichenb. & + \\
\hline Soldanella hungarica Simonk. & 2 & Picea abies (L.) H. Karst. (juv.) & + \\
\hline Nardus stricta L. & 2 & Cover of moss-lichen layer (\%) & 10 \\
\hline Festuca airoides Lam. & 1 & Cetraria islandica (L.) Ach. & 1 \\
\hline Juncus trifidus L. & 2 & Cladonia rangiferina (L.) Weber ex F.H. Wigg. & + \\
\hline Primula minima L. & 1 & Dicranum scoparium Hedw. & + \\
\hline Veronica baumgartenii Roem. \& Schult. & 2 & Polytrichastrum alpinum (Hedw.) G.L. Sm. & + \\
\hline Anthoxanthum odoratum L. & 2 & Polytrichum commune Hedw. & 1 \\
\hline Festuca picturata Pils & 2 & Polytrichum strictum Menzies ex Brid. & + \\
\hline Gentiana punctata L. & 1 & Thamnolia vermicularis (Sw.) Ach. ex Schaer. & 1 \\
\hline
\end{tabular}

\section{References}

Argus, G. W., Eckenwalder, J. E., \& Kiger, R. W. (2010). Salicaceae. In: Flora of North America Editorial Committee (Eds.), Flora of North America, vol. 7 (pp. 3-164). New York: Oxford University Press. Retrieved from http:// www.efloras.org/florataxon.aspx?flora id=1\&taxon_id=129059

Braun-Blanquet, J. (1964). Pflanzensoziologie. Grudzüge der Vegetationskunde. Wien: Verlag von Julius Springer.

Deyl, M. (1940). Plants, soil and climate of Pop Ivan: Synecological study from Carpathian Ukraine. Praha - Troja: Opera botan. Čechica.

Didukh, Y. P. (Ed.). (2009). Red Book of Ukraine. The plant kingdom. Kyiv: Globalconsulting. (In Ukrainian)
Dobrochaeva, D. N., Kotov, M. I., Prokudin, Y. N., Barbarych, A. I., Chopyk, V. I., Protopopova, V.V., Moroziuk, S. S., Dubovyk, O. N., Zyman, S. N., Sheliag-Sosonko, Y. R., Miakushko, T. Y., Zaverukha, B. V., Katina, Z. F., Skrypnyk, N. P., Kritskaya, L. I., Lypa, A. L., Mrinskiy, O. P., Alekseyev, Y. Y., Skvortsov, A. K., ... Ornst, E. Y. (1987). Identification key of higher plants of Ukraine. Kyiv: Naukova Dumka. (In Russian)

Elven, R., \& Karlsson, T. (2000). Salix L. In: B. Jonsell (Ed.), Flora Nordica. Vol. 1 (pp. 117-188). Stockholm: The Bergius Foundation.

Fuchylo, Y. D., \& Sbytna, M. V. (2009). Willows of Ukraine (biology, ecology, use). Kyiv: Logos. (In Ukrainian)

Gorelov, O. M. (2002). Family Salicaceae Mirbel. In M. A. Kokhno (Ed.), Dendroflora of Ukraine. Wild and cultivated trees and shrubs. Angiosperms. Part I (pp. 336-379). Kyiv: Phytosociocenter. (In Ukrainian) 
Jalas, J., \& Suominen, J. (Eds.). (1976). Atlas Florae Europaeae. Vol. 3. Salicaceae to Balanophorace. Helsinki: The Committee for Mapping the Flora of Europe \& Societas Biologica Fennica Vanamo.

Kobiv, Y. (2009). Global climate change as a threat to the species biodiversity in the high-mountain zone of the Ukrainian Carpathians. Ukrainian Botanical Journal, 66(4), 451-465. (In Ukrainian)

Kobiv, Y. (2010). Ecological characteristics of habitats of rare plant species in the Ukrainian Carpathians. Ukrainian Botanical Journal, 67(3), 355-372. (In Ukrainian)

Kobiv, Y., Prokopiv, A., Nachychko, V., Borsukevych, L., \& Helesh, M. (2017). Distribution and population status of rare plant species in the Marmarosh Mountains (Ukrainian Carpathians). Ukrainian Botanical Journal, 74(2), 163-176. https:// doi.org/10.15407/ukrbotj74.02.163

Kricsfalusy, V. V. (1982). Species of genus Salix L. in Ukrainian Carpathians. Ukrainian Botanical Journal, 39(2), 52-56. (In Ukrainian)

Kricsfalusy, V. V., Budnikov, G. B., \& Mihaly A. V. (1999). Red list of Transcarpathia. Threatened plant species and plant communities. Uzhgorod: Zakarpattya Publishing House. (In Ukrainian)

Malynovskyi, K. A. (1980). Highland vegetation of the Ukrainian Carpathians. Kyiv: Naukova Dumka Press. (In Ukrainian)
Meusel, H., Jäger, E., \& Weinert E. (1965). Vergleichende Chorologie der Zentraleuropäischen Flora. Bd. I. Jena: Gustav Fischer Verlag.

MycoBank. (2020). MycoBank Database. Retrieved from http://www.mycobank.org

Nazarov, M. I., Kotov, M. I., \& Gerzhedovych, P. I. (1952). Salicaceae (Salicaceae Lindl.). In M. I. Kotov (Ed.), Flora of the USSR. Vol. 4 (pp. 17-86). Moscow - Saint Petersburg: Publishing house of the Academy of Sciences of the USSR. (In Russian)

Prokopiv, A. I., \& Volgin, S. O. (2009). General characteristics of shoot system formation of Salix herbacea $\mathrm{L}$. in high-mountain zone of the Ukrainian Carpathians. Studia Biologica, 3(3), 8996. https://doi.org/10.30970/sbi.0303.055

The Plant List. (2013). The Plant List. Version 1.1. Published on the Internet. Retrieved from http:// www.theplantlist.org/

Thiers, B. (2020). Index Herbariorum: A global directory of public herbaria and associated staff. Retrieved from http://sweetgum.nybg.org/science/ih/

Tralau, H. (1963). The recent and fossil distribution of some boreal and arctic montane plants in Europe. Arkiv för Botanik, 5, 533-581.

Yaroshenko, P. D. (1961). Geobotany: basic concepts, directions and methods. Moscow - Saint Petersburg: Publishing House of Academy of Sciences of the USSR. (In Russian)

\section{Salix herbacea L. (Salicaceae) на Мармароському масиві в Українських Карпатах}

Р. Глеб ${ }^{1,2} *$, В. Лоя ${ }^{2}$ Р. Черепанин ${ }^{3}$

1 Карпатський біосферний заповідник, вул. Красне Плесо, 77, Рахів, 90600, Україна; * gleb.ruslan@gmail.com

2 Національний ботанічний сад імені М.М. Гришка НАН України, вул. Тімірязєвська, 1, Київ, 01014, Україна

3 Прикарпатський національний університет імені Василя Стефаника, вул. Шевченка, 57, ІваноФранківськ, 76018, Україна

Salix herbacea - це аркто-альпійський реліктовий вид з циркумполярним ареалом в межах голарктичної групи. Метою дослідження було уточнення даних щодо поширення S. herbacea в межах Мармароського масиву Українських Карпат, оскільки цей вид був зазначений для масиву без географічних деталей та опису середовища існування. Польові дослідження проводилися на Мармароському масиві на схилах гори Піп Іван (1936 м н.р.м.) та гори Рапа (1872 м н.р.м.) у 2017-2019 роках. Хорологія S. herbacea була проаналізована на основі даних інвентаризації гербарних колекцій UU, KW, KWHA, LW, Карпатського біосферного заповідника, а також кафедри біології та екології Прикарпатського національного університету імені Василя Стефаника. Описано оселище виду на туристичній стежці між вершинами гір Піп Іван Мармароський та Рапа Мармароського масиву в Рахівському районі Закарпатської області. Ця популяція приурочена до скель між вищезазначеними 
вершинами. Спостерігається заростання цих скельних угруповань високотравними видами Calamagrostis villosa, Poa pratensis та Festuca picturata. Відмічено витіснення голарктичних та альпійськокарпатських видів (Vaccinium uliginosum, Potentilla aurea, Pulsatilla alba, Thamnolia vermicularis та Cetraria islandica) високотравними видами. Ймовірно, ці процеси зумовлені зменшенням інтенсивності випасу худоби протягом останніх років у цій місцевості та сприятливішими для високотравних видів кліматичними умовами. Окреслено точне розташування та ценотичні умови оселища, що знаходиться під загрозою та потребує збереження. Наголошено на необхідності розробки та впровадження природоохоронних заходів для охорони оселища S. herbacea на Мармароському масиві.

Ключові слова: Salix herbacea, Українські Карпати, Мармароський масив, гербарні колекції, поширення, охорона 